\title{
A Comparison on soil biological health on continuous organic and inorganic farming
}

\begin{abstract}
To understand the soil health under continuous cultivation after using organic and chemical inputs, a survey was conducted under Uttarakhand, Navdanya farm areas, where farmers was selected who were practicing both chemical and organic inputs under different crops at least more than 5 years. The effect of most important crops growing under Uttarakhand i.e wheat, potato, garlic, mustard, chick pea, chilli and pumpkin was taken into consideration. The results clearly suggested that a significant decline in most important soil enzyme activities like dehydrogenase, esterase, acid and alkaline phosphatase under chemical farming as compared to organic farming. The microbial population especially fungi, bacteria, actinomycetes, azotobacter and nitrosomonas was significantly higher under organic farming areas than chemical farming. The results clearly showed that organic farming has a great role to maintain excellent microbial and enzyme activities resulted better soil health status.
\end{abstract}

Volume 2 Issue 5 - 2018

Indira Rathore, Vandana Shiva, Esther

Thomas, JC Tarafdar

ICAR-Central Arid Zone Research Institute, Jodhpur 342003,

Rajasthan, India

Correspondence: JC Tarafdar, ICAR-Central Arid Zone Research Institute, Jodhpur 342003, Rajasthan, India, Email jctarafdar@yahoo.in

Received: January 25, 2018 | Published: October 08, 2018

Keywords: soil health, organic input, chemical input, conventional farming, enzyme activity, microbial build up

\section{Introduction}

Agriculture is a critical sector of Indian economy. Increased use of chemicals, under intensive cultivation has disturbed the harmony existing among soil, plant and human health. ${ }^{1}$ Farmers are perusing chemical supplements to push crop yield, which is only harming the earth. Farmers and communities faced many socio-economic problems, particularly small farmers who found themselves increasingly marginalized due to lack of access to external inputs. Their soil is depleted from the constant application of harsh and harmful chemicals. The role of organic agriculture is to either enhance or sustain the overall quality and health of the soil ecosystem. ${ }^{2}$ Agricultural sustainability depends on productive soil. During the last several decades, much research has focussed on increasing productivity and protecting environmental quality under different farming systems. These studies show that conventional farming's use of chemical fertilizers and pesticides has increased crop yields and enhanced food security around the globe. ${ }^{3}$

However, despite the high yields associated with it, conventional farming's ability to sustain soil fertility and environmental quality has been called into question. ${ }^{3}$ Conventional farming systems are reported to be associated with decline in soil structure and soil aggregation, a decrease in water infiltration, an increase in soil bulk density, soil salinity, nitrogen leaching and ground water contamination., ${ }^{4,5}$ High soil quality is associated with efficient use of water, nutrients and pesticides, improvement of water and air quality, mitigation of green house gas emission, and increase in organic production. ${ }^{6}$ According to Scow et al. ${ }^{7}$ it takes about three to five years to stabilize soil properties following conversion from conventional to organic farming, and yields during the conversion period are often lower than those achieved later. Physical, chemical, biological and biochemical properties are involved in soil functioning, biological and biochemical properties tend to react quickly to changes in the external environment. ${ }^{8,9}$ Soil microbes play vital role in the biochemical cycling of elements in the biosphere where the essential elements undergo chemical transformation. Soil microorganisms, such as bacteria and fungi, control the functioning of ecosystem through decomposition and nutrient cycling which in turn may serve as ecosystem health. ${ }^{10-12}$ Organic farming has improved food quality and safety, because the nutrient supply and pest control methods are largely depend on biological processes in organic systems. ${ }^{13}$ It has been reported,,${ }^{14}$ that the soil enzyme activities and microbial population are higher in organically managed farming when compared to the conventional and integrated managed farming.

To determine a farming system's sustainability, an integrated assessment of biological soil health is essential on a field scale with continuous farming practice. Therefore, there is a need to clearly understand the net effect on organic farming as compared to conventionally chemical farming on soil biological health. The present study has been undertaken to compare the changes in beneficial microbial and enzyme activities in continuous organic farming and inorganic farming practices fewer than seven important crops of Uttarakhand, India.

\section{Materials and methods}

A survey work has been done at Uttarakhand (Navdanya farm surrounding areas $30.3165 \mathrm{~N}$ and $78.0322^{\circ} \mathrm{E}$ ) to understand the biological soil health in organic and chemical input growing areas. In general, between 8 and 20 years of same farming practice field (organic/chemical/no input) was considered for sampling. The total area covered for sampling under organic farming was 10.8 hectare and under chemical farming was 12.5 hectare of land. The soil samples were collected from the field of seven different crops (wheat, potato, garlic, mustard, chickpea, chilli, pumpkin) growing under absolutely organic farming, chemical farming and no-input condition. The treatments under organic farming were 4-6 tonnes FYM (Farm Yard Manure) or vermicompost per hectare and for chemical farming the recommended doses of NPK to the respective crops per hectare. The soil samples collected from the bunds (barren soils) was considered as absolute control. Four farmer's field was selected for each type 
of cultivation under each crop. Ten samples in zig- zag way was collected from each field of 5-30 cm depth and mixed them thoroughly to prepare a composite sample. The soil biological parameters were considered as dehydrogenase, esterase, acid phosphatase and alkaline phosphatase activities as well as fungi, bacteria, actinomycetes, nitrosomonas and azotobacter population.

\section{Dehydrogenase assay}

It was measured in soils immediately after soil sampling or in stored soils at $4^{\circ} \mathrm{C}$ (within 15 days). The activity was assayed by the method of Tabatabai. ${ }^{15}$ One gram of soil sample in triplicate was taken in screw cap test tube ( $15 \mathrm{~mL}$ capacity). To it, $0.2 \mathrm{~mL}$ of $3 \%$ TTC and $0.5 \mathrm{~mL} 1 \%$ glucose was added. After mixing the content, the tubes were incubated for $24 \mathrm{~h}$ at $30^{\circ} \mathrm{C}$. Once the process of incubation was over, $10 \mathrm{~mL}$ of methanol was added to it. The entire material was mixed thoroughly (for a min). After mixing, the tubes were placed in refrigerator for $3 \mathrm{~h}$. The production of triphenyl formazon was determined by measuring absorbance at $485 \mathrm{~nm}$.

\section{Acid and alkaline phosphatase activity}

It was assayed by adopting the standard procedure. ${ }^{16}$ The procedure described for assay of phosphomonoestrase activities is based on colorimetric estimation of the p-nitrophenol released by phosphatase activity when soil is incubated with buffered ( $\mathrm{pH} 5.4$ for acid phosphatase and $\mathrm{pH} 9.2$ for alkaline phosphatase) sodium p-nitrophenyl phosphate solution. One gram of soil in triplication were placed in $15 \mathrm{~mL}$ capacity screw cap test tube, $4 \mathrm{ml}$ of p-nitrophenyl phosphate solution prepared in acetate buffer $(\mathrm{pH} 5.4$ for assay of acid phosphatase) or borax- $\mathrm{NaOH}$ buffer ( $\mathrm{pH} 9.2$ for assay of alkaline phosphatase) was added and swirled the test tube for a few seconds to mix the contents. The test tube was covered with screw cap, and placed it in an incubator at $35^{\circ} \mathrm{C}$. After $1 \mathrm{~h}$, the cap was removed and $1 \mathrm{~mL}$ of $0.5 \mathrm{M} \mathrm{CaCl}_{2}$ and $4 \mathrm{~mL}$ of $0.5 \mathrm{M} \mathrm{NaOH}$ was added. The test tube was swirled for few seconds and the soil suspension was filtered through a whatman no. 42 filter paper. The yellow colour intensity of the filtrate was measured spectrophotometrically at $420 \mathrm{~nm}$ wave length.

\section{Enzyme unit}

The p-nitrophenol content of the filtrate was calculated against the standard curve wuith p-nitophenol. One unit is the amount of enzyme, which hydrolyses $1.0 \mu$ mole of p-nitrophenylphosphate per second at $\mathrm{pH} 5.4$ (acid phosphatase) or $\mathrm{pH} 9.4$ (alkaline phosphatase) at $35^{\circ} \mathrm{C}$. Estimation of esterase activity was made as described by Schnuver \& Rosswall. ${ }^{17} 0.5 \mathrm{~g}$ of soil samples were placed in a $(18 \times 150)$ test tube in triplicate and $10 \mathrm{~mL}$ sterile potassium phosphate buffer $(\mathrm{pH} 7.6$, $60 \mathrm{mM})$ was added to it. One $\mathrm{mL}$ of fluorescent diacetate $\left(1 \mathrm{mg} \mathrm{mL}^{-1}\right.$ in acetone) was poured and the tubes were sealed and kept in an incubtor at $37^{\circ} \mathrm{C}$ for $4 \mathrm{~h}$. After that the reaction was stopped by addition of $10 \mathrm{~mL}$ of acetone. The mixture was shacked and filtered through whatman No. 42 filter paper and the supernatant optical density was determined in $490 \mathrm{~nm}$ on spectrophotometer.

\section{Microbial population}

Microbial population was estimated by serial dilution technique ${ }^{18}$ using selective media as described. ${ }^{19}$

\section{Statistical analysis}

The data were subjected to analysis of various and the least significant differences (LSD) were used to separate means. ${ }^{20}$

\section{Results}

\section{Beneficial enzymes}

The dehydrogenase activity indicates the activity of bacteria and actinomycetes in the soils under different growing conditions. The dehydrogenase activity under organic, chemical and no input conditions of seven different crops studied was presented in Table 1. The results (Table 1) clearly indicate that there was no significant difference in dehydrogenase activity in absolute control soil where no plants were growing. The dehydrogenase activity varies due to the farming practice and the crops under cultivation. The improvement in dehydrogenase activity, irrespective of crops, was much higher under organic than chemical farming (Figure 1). The much higher dehydrogenase activity (300\%) was observed under mustard crop and the least improvement was noticed under pumpkin crop (64.1\%). In general, organic farming results $39-127 \%$ improvement in dehydrogenase activity over the absolute control soil under the similar crop growing condition. On the other hand chemical farming yields $2-23 \%$ less dehydrogenase activity when compared with no input soil. The results clearly indicate the adverse effect of chemical farming under different crops. The plant contribution and soil contribution to dehydrogenase activity was also partitioned. It was found that there was great variation among the crops. The soil contribution was found to be much higher, in general, than plant contribution. The overall results showed $64.2 \%$ activities of dehydrogenase contributed by soil and $35.8 \%$ were contributing by plants. On an average, $18 \%$ decline in dehydrogenase activity was observed when chemical farming was practiced as compared to no input (no chemical, no organic), which also clearly indicated that chemical farming has an adverse effect on soil dehydrogenase activity. The results also showed that organic farming promotes dehydrogenase activity, in general, by $43 \%$ as compared to the crops growing under no input land. The most negative effect toward dehydrogenase activity under chemical farming was noticed on pumpkin crop followed by chickpea and mustard crop (Figure 1).

Table I Dehydrogenase activity (pkat/g) under different crops and farming practice

\begin{tabular}{lllll}
\hline Crops & Control * & No input & $\begin{array}{l}\text { Chemical } \\
\text { farming }\end{array}$ & $\begin{array}{l}\text { Organic } \\
\text { farming }\end{array}$ \\
\hline Wheat & 0.79 & $\mathrm{I} .55$ & $\mathrm{I} .52$ & 2.35 \\
Potato & 0.8 & $\mathrm{I} .48$ & $\mathrm{I} .43$ & $\mathrm{I} .79$ \\
Garlic & 0.8 & $\mathrm{I} .16$ & $\mathrm{I} .05$ & $\mathrm{I} .49$ \\
Mustard & 0.79 & $\mathrm{I} .39$ & $\mathrm{I} .13$ & 3.16 \\
Chick pea & 0.79 & $\mathrm{I}$ & 0.8 & $\mathrm{I} .45$ \\
Chilli & 0.8 & $\mathrm{I} .47$ & $\mathrm{I} .3 \mathrm{I}$ & 2.34 \\
Pumpkin & 0.78 & 0.92 & $0.7 \mathrm{I}$ & $\mathrm{I} .28$ \\
LSD(p=0.05) & 0.15 & 0.23 & $0.3 \mathrm{I}$ & 0.38 \\
\hline
\end{tabular}

*barren land, no crops 


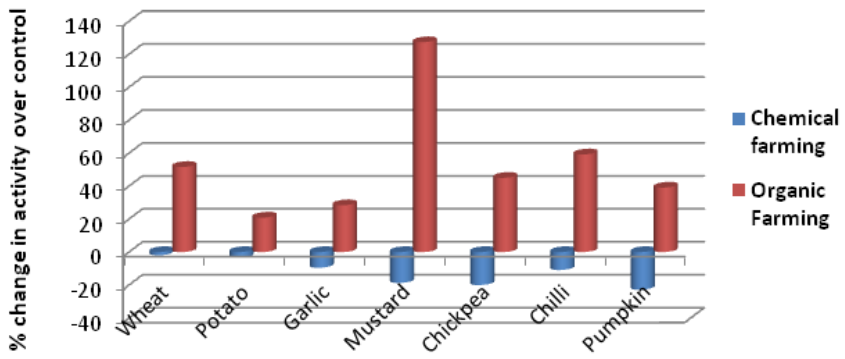

Figure I Changes in dehydrogenase activity under chemical and organic farming.

The activity of fungi, bacteria and actinomycetes in the soil (Esterase activity) under study resulted; 2-8.7 fold improvement in esterase activity under different crop rhizosphere (Table 2). Organic farming practice has more esterase activity under wheat followed by mustard. Although there were little differences in esterase activity under control soil of different crops but the results showed consistently higher in esterase activity (28-56\%) under organic farming soils over chemical farming. Chemical farming also resulted up to $12 \%$ decline in esterase activity as compared to absolute control i.e. no input land (Figure 2). A comparison of plant and soil contribution towards esterase activity was made and it was found that $60.4 \%$ esterase activity was contributed by plants whereas soil contribution was only $39.6 \%$. In general, more plant contribution was noticed under garlic and least under pumpkin whereas more soil contribution was observed under chilli (Figure 2). Acid phosphatase mainly contributed by the plants and microorganisms in soil. Phosphatase enzymes helps in hydrolysis of C-O-P ester bond of organic phosphorus in plant available inorganic $\mathrm{P}$ in phosphate form. The activity of acid phosphatase under different input as well as seven crops was presented in Table 3 . In general, there were no differences in acid phosphatase activity under no crop condition of different crops land. However the results showed more influence of acid phosphatase in organic farming where 3-6 fold improvement in activities was noticed as compared to absolute control. The maximum improvement was obtained in wheat followed by chick pea. In general, $38.7 \%$ more acid phosphatase activity was found in organic farming than chemical farming (Figure 3), where at least in two different crops (mustard and chilli) the activities under chemical farming decline than no input land. Except mustard, garlic and chilli all other crops had higher acid phosphatase activity under chemical farming as compared to no input crops.

Table 2 Esterase activity $\left(E U \times 10^{-3}\right)$ under different crops and farming practice

\begin{tabular}{lllll}
\hline Crops & Control * & No input & $\begin{array}{l}\text { Chemical } \\
\text { farming }\end{array}$ & $\begin{array}{l}\text { Organic } \\
\text { farming }\end{array}$ \\
\hline Wheat & 2.4 & 6.7 & 6.4 & 23.3 \\
Potato & 2.6 & 7.3 & 7.2 & 17.9 \\
Garlic & 2.8 & 9.7 & 9.4 & 22.6 \\
Mustard & 4.1 & 12.8 & 12.4 & 36.9 \\
Chick pea & 3.8 & 10.3 & 9.4 & 14.1 \\
Chilli & 4.2 & 7.8 & 6.9 & 20.7 \\
Pumpkin & 3.2 & 5.9 & 5.8 & 12.7 \\
LSD $(p=0.05)$ & 0.9 & 1.3 & 1.9 & 2.1 \\
\hline
\end{tabular}

*barren land, no crops

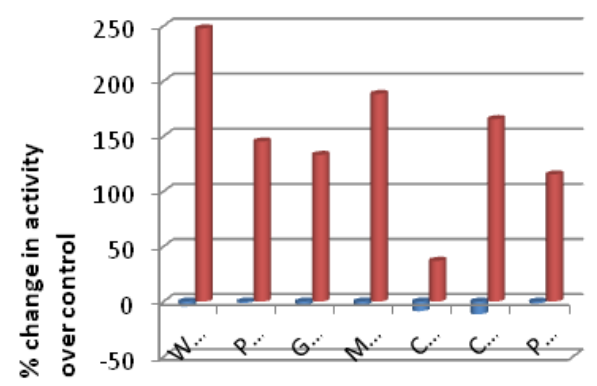

Chemical Farming

- Organic farming

Figure 2 Changes in esterase activity under chemical and organic farming.

Table 3 Acid phosphatase $\left(\mathrm{EU} \times 10^{-3}\right)$ under different crops and farming practice

\begin{tabular}{lllll}
\hline Crops & Control* & No input & $\begin{array}{l}\text { Chemical } \\
\text { farming }\end{array}$ & $\begin{array}{l}\text { Organic } \\
\text { farming }\end{array}$ \\
\hline Wheat & 0.6 & 1.8 & 4 & 4.2 \\
Potato & 0.8 & 2.8 & 3.2 & 3.9 \\
Garlic & 0.9 & 3.4 & 3.4 & 4 \\
Mustard & 0.8 & 2.6 & 2.5 & 4.3 \\
Chick pea & 0.7 & 2.5 & 3.2 & 4.3 \\
Chilli & 0.8 & 2.9 & 2.8 & 4.4 \\
Pumpkin & 0.8 & 2.7 & 3.3 & 4.2 \\
LSD(p=0.05) & 0.3 & 0.7 & 0.9 & 0.8 \\
\hline
\end{tabular}

*barren land, no crops

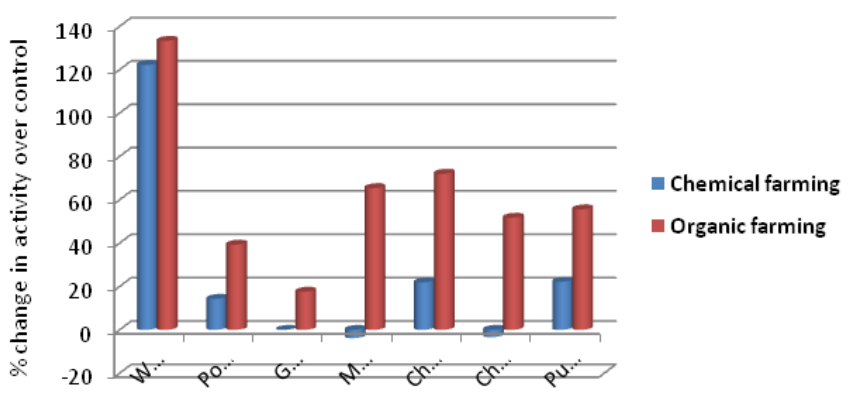

Figure 3 Changes in acid phosphatase activity under chemical and organic farming.

Alkaline phosphatase is only contributing by microorganisms present in the soil. They are also equally effective in breaking down the C-O-P ester bond to bring phosphorus into phosphate form for plant availability. In general, organic farming results $25-100 \%$ improvement in alkaline phosphatase activity (Table 4) as compared to soil of absolute control. Potato crop growing areas showed more improvement in alkaline phosphatase activity followed by garlic. The results clearly showed that there were hardly any differences in alkaline phosphatase activity under no crop (control) land but up 
to $18 \%$ decline in alkaline phosphatase activity over no input land when crops were growing under chemical farming. However, 10$40 \%$ improvement in alkaline phosphatase activity was noticed when farmers are practicing organic farming (Figure 4). The result indicated tremendous contribution of organic farming on alkaline phosphatase activity. In general, between the farming systems, the alkaline phosphatase activity under chemical farming was $73.4 \%$ less than organic farming irrespective of the crops cultivated. Except mustard, all other crops showed negative impact of alkaline phosphatase activities under chemical farming (Figure 4). The decline in alkaline phosphatase activity under potato was more (18.2\%) followed by garlic (16.7\%) and pumpkin (15.4\%), which indicate an adverse effect on soil health due to chemical farming practice.

Table 4 Alkaline phosphatase $\left(E U \times 10^{-3}\right)$ under different crops and farming practice

\begin{tabular}{lllll}
\hline Crops & Control* & No input & $\begin{array}{l}\text { Chemical } \\
\text { farming }\end{array}$ & $\begin{array}{l}\text { Organic } \\
\text { farming }\end{array}$ \\
\hline Wheat & 0.6 & $\mathrm{I}$ & 0.9 & $\mathrm{I} .1$ \\
Potato & 0.7 & $\mathrm{I} .1$ & 0.9 & $\mathrm{I} .4$ \\
Garlic & 0.8 & 1.2 & $\mathrm{I}$ & $\mathrm{I} .5$ \\
Mustard & $\mathrm{I}$ & $\mathrm{I}$ & $\mathrm{I}$ & $\mathrm{I} .4$ \\
Chick pea & 0.9 & 0.9 & 0.8 & $\mathrm{I} .2$ \\
Chilli & 0.8 & $\mathrm{I}$ & 0.9 & $\mathrm{I} .4$ \\
Pumpkin & 0.9 & 1.3 & 1.1 & 1.5 \\
LSD9p=0.05) & 0.3 & 0.4 & 0.4 & 0.7 \\
\hline
\end{tabular}

*barren land, no crops

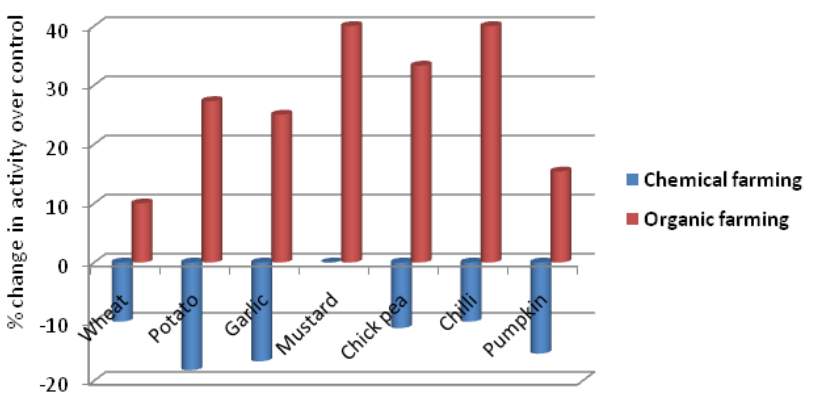

Figure 4 Changes in alkaline phosphatase activity under chemical and organic farming.

\section{Microbial population}

The fungi population on different crops was increased over control soil between 6 and 36 fold (Table 5) when organic farming was practiced. The population was much less under chemical farming (Figure 5). Except mustard, all other crops showed decline in fungal population under chemical farming than no input cultivation. The mustard field showed there was $59.7 \%$ improvement in the population under chemical farming than no input land which was further enhanced to $14-47 \%$ under organic farming. The more increase in fungal population was observed when mustard was grown in organic farming followed by potato. In general, $90 \%$ reduction in fungal population was observed under chemical farming as compared to organic farming growing plants although hardly any difference in population was observed under control soil (Table 5). The most affected crops due to chemical farming seems to be potato and chick pea. It was noticed that plant contribution for fungal population development was much higher than soil contribution. The reduction in population due to chemical farming varies between $2.5-49.7 \%$ under different crops than no input agriculture. However, up to 16 fold improvement in fungal population was noticed due to organic farming practice when compared with no input crops (Figure 5). Organic farming enhances bacteria population between 1.8- 6.2 fold under different crops (Table 6 ), which was $78 \%$ more build up than chemical farming. The higher build up was noticed under pumpkin followed by chilli and wheat. The plant contribution towards bacteria population was noticed between 42 and $66 \%$. The reduction on population due to chemical farming over no input crop was between 5 and $33 \%$, which was more under mustard followed by garlic. In general, $50-241 \%$ increase in bacteria population was observed under organic farming over no input land. The adverse effect of chemical farming in bacterial population was obvious and it was more alarming especially under mustard, chick pea and garlic (Figure 6). The population build up under organic farming was found to be very effective under wheat followed by pumpkin among the seven crops compared. Organic farming build up $47-483 \%$ more actinomycetes population under seven crops tested (Table 7). The results showed more plant contribution under mustard (52.9\%) to build up actinomycetes population.

Table 5 Fungi (CFU $\times 10^{3} / g$ ) population under different crops and farming practice

\begin{tabular}{lllll}
\hline Crops & Control* & No input & $\begin{array}{l}\text { Chemical } \\
\text { farming }\end{array}$ & $\begin{array}{l}\text { Organic } \\
\text { farming }\end{array}$ \\
\hline Wheat & 5.5 & 22 & 20 & 66.5 \\
Potato & 3.5 & 7 & 6 & 120 \\
Garlic & 7 & 20 & 19.5 & 94 \\
Mustard & 3 & 7.2 & 11.5 & 111 \\
Chick pea & 6.5 & 18.7 & 8 & 180 \\
Chilli & 8.5 & 20 & 14 & 160 \\
Pumpkin & 7 & 14.1 & 12 & 52 \\
LSDp $(=0.05)$ & 4.2 & 7.3 & 6.5 & 11.1 \\
\hline
\end{tabular}

*barren land, no crops

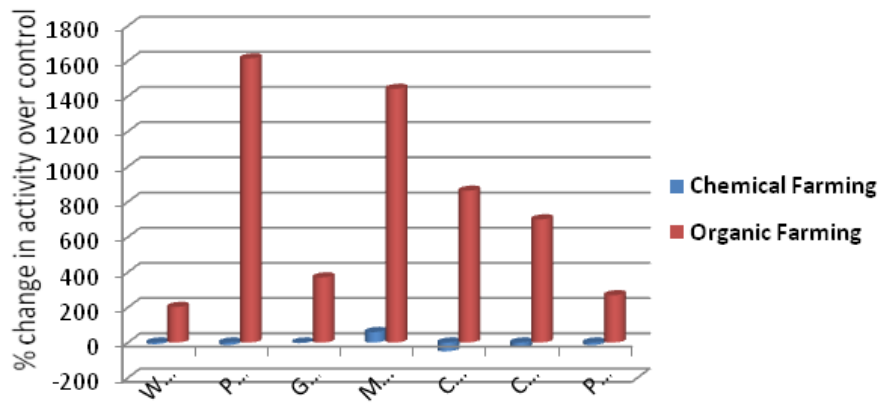

Figure $\mathbf{5}$ Changes in fungi population under chemical and organic farming. 
Table 6 Bacteria (CFUx105/g) population under different crops and farming practice

\begin{tabular}{lllll}
\hline Crops & Control* & No input & $\begin{array}{l}\text { Chemical } \\
\text { farming }\end{array}$ & $\begin{array}{l}\text { Organic } \\
\text { farming }\end{array}$ \\
\hline Wheat & 2.5 & 4.4 & 4 & 15 \\
Potato & 3 & 8.4 & 8 & 12 \\
Garlic & 4.5 & 10.4 & 7 & 26 \\
Mustard & 3.5 & 6 & 4 & 10 \\
Chick pea & 5 & 9.3 & 7 & 14 \\
Chilli & 2 & 5.8 & 5.5 & 12.5 \\
Pumpkin & 4 & 8.8 & 8 & 29 \\
LSD $(\mathrm{P}=0.05)$ & 1.7 & 1.9 & 1.8 & 3.5 \\
\hline
\end{tabular}

*barren land, no crops

Table 7 Actinomycetes (CFUxI04/g) population under different crops and farming practice

\begin{tabular}{lllll}
\hline Crops & Control* $^{*}$ & No input & $\begin{array}{l}\text { Chemical } \\
\text { farming }\end{array}$ & $\begin{array}{l}\text { Organic } \\
\text { farming }\end{array}$ \\
\hline Wheat & 34 & 43 & 39 & 50 \\
Potato & 39 & 45 & 40 & 67 \\
Garlic & 22 & 24 & 21 & 56 \\
Mustard & 17 & 26 & 24 & 85 \\
Chick pea & 18 & 23 & 22 & 105 \\
Chilli & 20 & 24 & 24 & 45 \\
Pumpkin & 25 & 30 & 28 & 70 \\
LSD (p=0.05) & 7.1 & 11.2 & 8.7 & 13.5 \\
\hline
\end{tabular}

*barren land, no crops

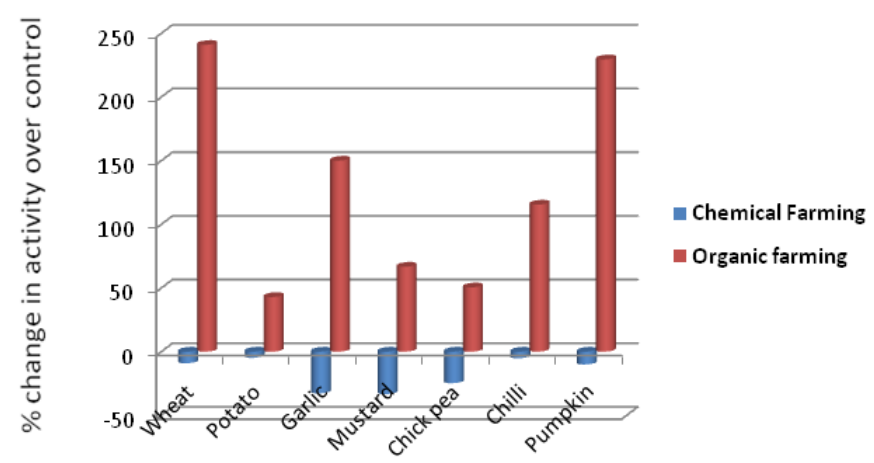

Figure 6 Changes in bacteria population under chemical and organic farming.

However, garlic showed (9.1\%) least plant contribution towards build up of the organisms. The reduction in activity due to chemical farming was between $0-13 \%$, which was more under garlic and least under chilli. The results showed $93 \%$ more build up of actinomycetes population under organic farming as compared to chemical farming (Figure 7). The maximum response to organic farming was observed under chick pea (356.5\%) followed by mustard $(226.9 \%)$. The least effect due to organic farming was observed under wheat $(16.3 \%)$. It was very clear from the results that organic farming has definite edge over chemical farming and no input land to build up different organism's population under the rhizosphere of different crops grown in this region. Azotobacter is a free living nitrogen fixer, can fix nitrogen from the atmosphere without any outside help. In our study, their population was tremendously improved (up to 10 fold) due to organic farming practice under different crops (Table 8). It was more under mustard followed by potato and pumpkin. Although there was no significant difference in azotobacter population to the barren land soil used for cultivation of seven crops tested.

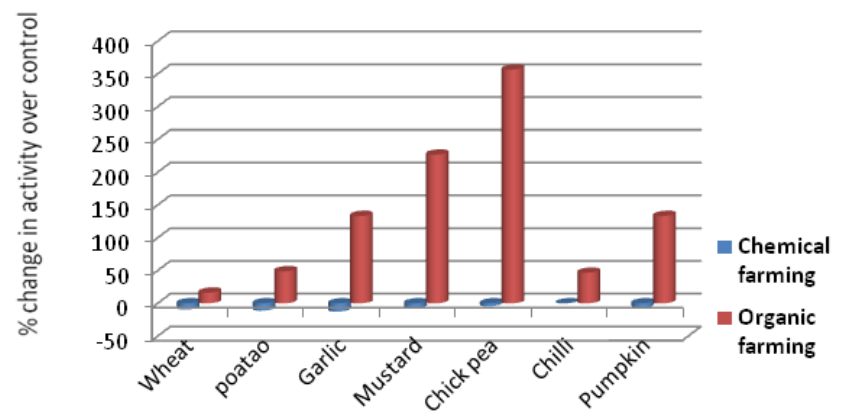

Figure 7 Changes in actinomycetes population under chemical and organic farming.

Table 8 Azotobacter $\left(\mathrm{CFU} \times 10^{2} / \mathrm{g}\right)$ population under different crops and farming practice

\begin{tabular}{lllll}
\hline Crop & Control* & No input & $\begin{array}{l}\text { Chemical } \\
\text { farming }\end{array}$ & $\begin{array}{l}\text { Organic } \\
\text { farming }\end{array}$ \\
\hline Wheat & 0.5 & 1.4 & 1.5 & 3 \\
Potato & 0.4 & $\mathrm{I}$ & $\mathrm{I}$ & 4 \\
Garlic & 0.5 & 0.9 & 0.6 & $\mathrm{I}$ \\
Mustard & 0.5 & 0.5 & 0.1 & 5.5 \\
Chick pea & 0.3 & 0.4 & 0.1 & 2 \\
Chilli & 0.4 & 0.6 & 0.5 & 3 \\
Pumpkin & 0.5 & 0.8 & 0.7 & 5 \\
$\operatorname{LSD}(\mathrm{p}=0.05)$ & 0.3 & 0.4 & 0.5 & 0.8 \\
\hline
\end{tabular}

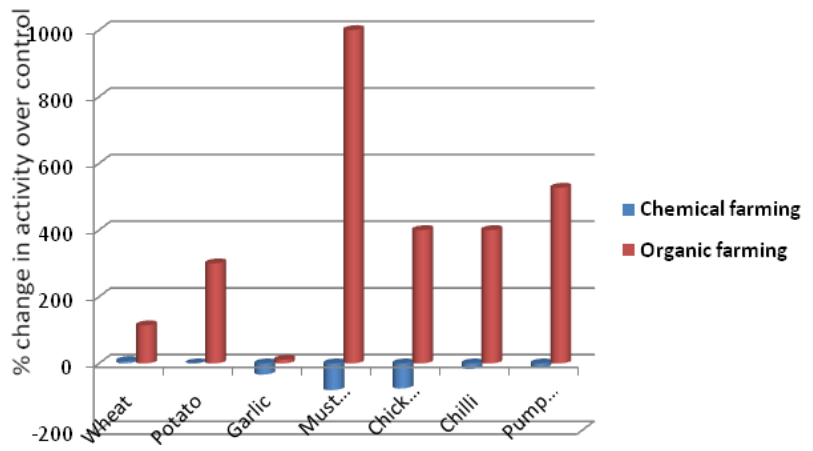

Figure 8 Changes in Azotobacter population under chemical and organic farming. 
In most of the crops showed an adverse effect on Azotobacter population when chemical farming was practiced as compared to no input condition. The result suggested that organic farming may booster nitrogen fixer population in the soil where in almost all the crops showed 1-10 fold increase in population accept garlic where organic farming resulted only $11.1 \%$ improvement in Azotobacter population (Figure 8). Except under mustard all other crop shows significant plant contribution (25-64.3\%) to build up Azotobacter population in the soil. The highest contribution was found under wheat followed by potato. Nitrosomonas helps in transformation of nitrogen in plant available form, which was much higher (between 75 and $354 \%$ ) under organic farming as compared to the chemical farming (between -24 and 102\%). Organic farming under potato resulted more build up of population followed by wheat and pumpkin (Table 9). The results showed up to $54 \%$ influence on build up in nitrosomonas population under potato followed by garlic $(33 \%)$ whereas wheat crop showed least influence on build up of nitrosomonas population. There was $36 \%$ reduction in nitrosomonas population under wheat when chemical farming was practiced. The least reduction $(-1.5 \%)$ was observed under potato followed by pumpkin (-9.4\%). Organic farming enhance nitrosomonas population between 36 and $160 \%$ than no input land (Figure 8 ) which was more under wheat and least under chick pea. The results suggested in enhancing nitrifying bacterial population, organic farming has a great role.

Table 9 Nitrosomonas (CFU $\mathrm{g}^{-1}$ ) population under different crops and farming practice

\begin{tabular}{lllll}
\hline Crops & Control* & No input & $\begin{array}{l}\text { Chemical } \\
\text { farming }\end{array}$ & $\begin{array}{l}\text { Organic } \\
\text { farming }\end{array}$ \\
\hline Wheat & 29 & 30 & 22 & 78 \\
Potato & 31 & 67 & 66 & 141 \\
Garlic & 28 & 42 & 35 & 60 \\
Mustard & 29 & 39 & 35 & 57 \\
Chick pea & 30 & 39 & 33 & 53 \\
Chilli & 28 & 35 & 24 & 49 \\
Pumpkin & 30 & 35 & 32 & 75 \\
LSD ( $=0.05)$ & 5.1 & 7.3 & 6.9 & 13 \\
\hline
\end{tabular}

*barren land, no crops

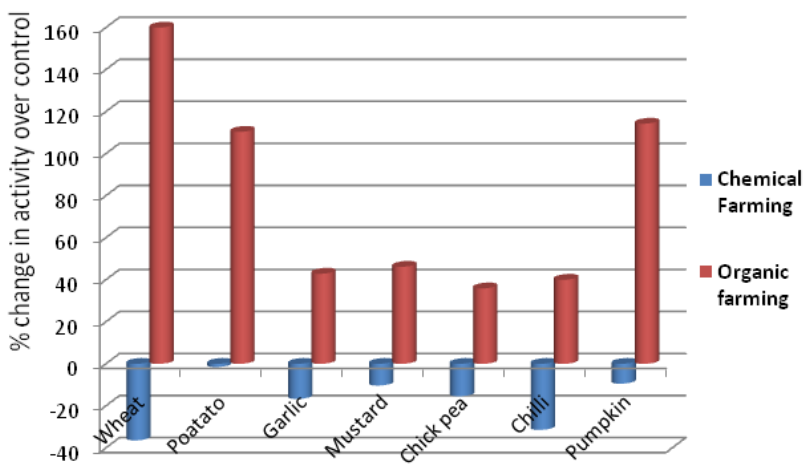

Figure 9 Changes in Nitrosomonas population under chemical and organic farming.

\section{Discussion}

We found that significant improvement in microbial population and enzyme activities in the soil under different crops due to organic farming practice than chemical and no input farming. For organic farming systems, nutrient cycling and relative ability of the soil for nutrients can be high. ${ }^{21}$ Compost contains bacterial, actinomycetes, and fungi; hence a fresh supply of humic material not only added microorganisms but also stimulated them. ${ }^{22,23}$ Composting material added plenty of carbon and thus increased heterotrophic bacteria and fungi in soil and farther increased the activity of soil enzymes responsible for the conversion of available form of nutrient. ${ }^{24}$ The higher soil microbial activity due to organic farming may be higher soil respiration due to the stimulation of heterotrophic microorganisms. ${ }^{25}$ Other comparisons of the conventional and organic farming systems have also reported an increase in the soil microbial respiration under organic management. ${ }^{26,27}$ In our result organic farming has higher bacterial, fungal, actinomycetes, Azotobacter and Nitrosomonas population compared to chemical and no-input farming systems. The applications of animals' manures and compost increase in activity and diversity of the microbial community ${ }^{28}$ such enhancement to the soil microbial community might have benefits for plants productivity through increased nutrient cycling rate. ${ }^{29}$

Besides compost played an important role in control of plant nematodes and in mitigating the effect of pesticides and limits degradation as well as transport in soil, Farm Yard Manure or vermicompost added plenty of carbon and thus increased heterotrophic bacteria and fungi in soil and further increased the activity of soil enzymes responsible for the conversion of unavailable to available form of nutrients. Densities of bacteria, protozoa, nematodes, and arthopodes in soils under organic farming were higher than conventional farming. ${ }^{24,30}$ Organic agriculture also reduces the risk of yield failure, stabilizes returns and quality of soil health. ${ }^{31}$ This study shows further evidence as to organic farming is improving the soil health and quality without affecting the environment.

\section{Acknowledgements}

None.

\section{Conflict of interest}

Authors declare that there is no conflict of interest.

\section{References}

1. Thirppeswamy, E. Comparative analysis of organic and inorganic food. IOSR J Agril Vet Sci. 2013;4:53-57.

2. Ekwue EI. Effect of organic and fertilizer treatments on soil physical properties and erodibilities. Soil Till Res. 1992;22(3-4):199-209.

3. Pang XP, Letey J. Organic farming: challenge of timing nitrogen availability to crop nitrogen requirements. Soil Sci Soc America J. 2000;64(1):247-253.

4. Logsdon SD, Radke JK, Karlen DL. Comparison of alternative farming systems. I. infiltration techniques. Amer J alternate Agril. 1993;8:15-20.

5. Mc Garry DG, Bridge BJ, Radford BJ. Contrasting soil physical properties after zero and traditional tillage of an alluvial soil in the semiarid subtropics. Soil Till Res. 2000;53(2):105-115. 
6. Lal R. Methods and guidelines for assessing sustainable use of soil and water resources in the tropics. Washington: Soil management support services; 1994.

7. Scow KM, Somasco O, Gunpala N, et al. Transition from conventional to low input agriculture changes soil fertility and biology. California Agril. 1994;48:20-26.

8. Nannipieri P, Ceccanti B, Grego S. Ecological significance of biological activity in soil. In: Bollag JM, Stotzky G, Editors. Soil Biochemistry. New York: Marcel Dekker; 1990;6:293-354.

9. Vanhala P, Ahtianen JH. Soil respiration, ATP content and photobacterium toxicity test as indicators of metal pollution in soil. Environ Toxicol Water quality. 1994;9(2):115-121.

10. Doran JW, Zeiss MR. Soil health and sustainability: managing the biotic component of soil quality. Appl Soil Ecol. 2000;15:3-11.

11. Waldrop MP, Balser TC, Firestone MK. Linking microbial community composition to function in a tropical soil. Soil Biol Biochem. 2000;32(13):1837-1846.

12. Yao $\mathrm{H}, \mathrm{He} \mathrm{Z}$, Wison MJ, et al. Microbial biomass and community structure in a sequence of soils with increasing fertility and changing land use. Microbial Ecol. 2000;40(3):223-237.

13. Colin Macilwain. Organic: is the future of farming? Nature. 2004;428:792 798.

14. Tarafdar JC, Tripathi KP, Kumar M. Organic Agriculture. Scientific Publisher. 2008. 369 p.

15. Tabatabai MA. Soil enzymes. In methods of soil analysis. Parr I. AL Page, RH Miller, DR Keeney, Editors. Agronomy. 1982;9:903-947.

16. Tabatabai MA, Bremner JM. Use of p-nitro phenyl phosphate for assay of soil phosphatase activity. Soil Biol Biochem. 1969;1(4):301-307.

17. Schnüver J, Rosswall T. Fluorescein di-acetate hydrolysis as a measure of total microbial activity in soil and litter. Appl Environ Microbiol. 1982;43:1256-1261.

18. Allen ON. Experiments in soil bacteriology. $3^{\text {rd }}$ ed. Burgess publishing. 1957.

19. Tarafdar JC, Yadav BK. A Hand Book of Soil Analysis. Agrobios. 2013 $198 \mathrm{p}$.
20. Sokal RR, Rohlf FJ. Biometry-The principles and practice of statistics in biological Research. New York: Trove; 1981

21. Reganold JP. Comparisons of soil properties as influenced by organic and conventional farming systems. Amer J Alternate Agril. 1988;3(4):144 155.

22. Balasubramanian A, Siddaramappa R, Rangaswami G. Effect of organic manuring on the activities of the enzymes hydrolysing suxrose and urea and on soil aggregation. Plant soil. 1972;37:319-328.

23. Gaur AC, Sadasivam OP, Vimal RS, et al. Studies on the humification of organic matter in a red rakar soil. Zentralblatt fur Bakteriologie. 1973;128(1):149-161

24. Sharma KN, Namdeo KN. Effect of bio-fertilizers and phosphorus on growth and yield of soybean (Glycine max L. merill). Crop Res. 1999; 17:160-163

25. Ademir SF Araujo, Luiz FC Leite, Valdinar B Santos, et al. Soil microbial activity in conventional and organic agricultural systems. Sustainability. 2009;1:268-276.

26. Glover JD, Reganold JP, Andrews PK. Systematic methods for rating soil quality of conventional organic and integrated apple orchards in Washington State. Agril Ecosys Envirn. 2000;80(1-2):29-44.

27. Helweg A. Microbial activities in soil from orchards reguraly treated with pesticides compared to the activity in soils without pesticides (organically cultivated). Pedobiologia. 1988;32:273-281.

28. Hassink J. Density fractions of soil macroorganic matter and microbial biomass as predictors of $\mathrm{C}$ and $\mathrm{N}$ mineralization. Soil Biol Biochem. 1995;27(8):1099-1108

29. Gajda A, Martyniuk S, Stachyra A, et al. Relations between microbiological and biochemical properties of soil under different agrotechnical conditions and its productivity. Pol J Soil Sci. 2000;33(2):55-60.

30. Wu S, Ingham ER. Hu D. Soil microfloral and faunal populations in an organic ecosystems in Oregan, USA. In proceedings of the $17^{\text {th }}$ world congress of soil science 5, 1756. Thailand: Queen Sirkit National Convention Centre; 2002

31. Kilcher L. How organic agriculture contributes to sustainable development. JARTS Supplements. 2007;89:31-49. 